\title{
ЯНТАРЬ ИЗ РАСКОПОК СРЕДНЕВЕКОВОГО ГОРОДИЩА РОДАНОВО НА ТЕРРИТОРИИ ПЕРМСКОГО КРАЯ ${ }^{1}$
}

\author{
(C) 2021 г. А.Н. Сарапулов, И. Г. Мокрушин, М. П. Красновских, П.А. Иванов, \\ О.Ю. Каменщиков, Ю.А. Подосёнова
}

Статья посвящена физико-химическому и историко-культурному изучению кусков необработанного янтаря-сырца, обнаруженных в культурном слое бронзолитейной и ювелирной мастерской XI - начала XII вв. Роданова городища. Данные находки на территории Пермского Предуралья обнаружены впервые. С целью решения вопроса о месте происхождения янтаря было проведено исследование по его идентификации. При помощи методов синхронного термического анализа, инфракрасной спектроскопии, сканирующей электронной микроскопии, анализа микротвердости, исследования на газовом хроматографе с масс-спектрометрическим детектором было доказано, что янтарь имеет прибалтийское происхождение. Сделан вывод о том, что находки могли попасть на городище с территорий древнерусских городов или через Волжскую Болгарию и использовался местными мастерами-ювелирами для обработки в качестве поделочных камней для вставок в ювелирные украшения.

Ключевыеслова: археология, ПермскоеПредуралье, Родановогородище, X-XIV вв., бронзолитейная и ювелирная мастерская, янтарь, физико-химические методы исследования, ювелирные украшения, прибалтийский регион, Древняя Русь, Волжская Болгария.

\section{AMBER FROM THE EXCAVATIONS OF RODANOVO MEDIEVAL HILLFORT IN PERM KRAI ${ }^{2}$}

\section{A.N. Sarapulov, I.G. Mokrushin, M.P. Krasnovskikh, P.A. Ivanov, O.Yu. Kamenshikov, Yu.A. Podosyonova}

The paper addresses the physical-chemical and historical-cultural study of the pieces of raw amber discovered in the cultural layer of a bronze casting and jewelry workshop of the $11^{\text {th }}-$ early $12^{\text {th }}$ centuries at Rodanovo hillfort. Such items were discovered in the territory of the Perm Cis-Urals for the first time. In order to resolve the issue of the place of origin of the amber, a study was conducted for its identification. Using the methods of synchronous thermal analysis, infrared spectroscopy, scanning electron microscopy, microhardness analysis, and gas chromatography studies with a mass spectrometric detector, it was confirmed that amber is of Baltic origin. It was concluded that the finds could have come to the hillfort from the territories of ancient Russian cities or through Volga Bolgaria, and were used by local jewelers for processing as ornamental stones for jewelry inserts.

Keywords: archaeology, Perm Cis-Urals, Rodanovo hillfort, X-XIV centuries, bronze casting and jewelry workshop, amber, physical and chemical research methods, jewelry, Baltic region, Ancient Russia, Volga Bulgaria.

Роданово (Полютово) городище находится в Юсьвинском районе Пермского края, на высоком правом берегу Камского водохранилища. Площадка городища овальной формы. С юга и севера ее ограничивают овраги, с востока - резкий обрыв к р. Каме. С западной части площадку памятника дугой огибают вал и ров, хорошо читаемые с напольной стороны.

До начала 90-х гг. XX в. площадка городища распахивалась и использовалась под огороды. Культурный слой памятника ежегодно разрушается береговой абразией и осыпается в p. Каму (от 0,5 до 1,0 м в год). О городище известно с XVIII в. Впервые изделия разного назначения, обнаруженные на городище, были опубликованы А.А. Спициным в начале XX в.

Исследование выполнено при финансовой поддержке РФФИ и Пермского края в рамках научного проекта № 20-49-590001 «Средневековое ювелирное наследие Пермского края: стилистические и химикотехнологические особенности» и при поддержке Министерства образования и науки Пермского края, соглашение № C-26/1192 от 19.12.2019 г.

2 The work was financially supported by a grant of the Russian Foundation for Basic Research, project No. 20-49590001 "Medieval Jewelry Heritage of Perm Krai: Stylistic and Chemical-Technological Features" and with the support of the Ministry of Education and Science of Perm Krai, Agreement No. C-26/1192 dated December 19, 2019. 
(Спицин, 1902, табл. XIX, 8; XXIV, 27; XXV, 9). В советское время исследования данного района проводила экспедиция Государственной академии истории материальной культуры. В 1932 г. А.В. Шмидтом на городище были заложены два пробных раскопа (Разведочные работы А.В. Шмидта...). В 1935 г. еще один пробный раскоп заложил Н.В. Прокошев. В раскопе был обнаружен клад украшений из 34 предметов, завернутый в бересту (Отчет Н.А. Прокошева...). В 1936-1937 гг. работы на городище были продолжены М.В. Талицким (Талицкий). В 1951 г. была опубликована обобщающая работа М.В. Талицкого, посвященная Верхнему Прикамью в X-XIV вв., основанная на материалах раскопок Роданова городища. На основании раскопок данного городища была выделена родановская археологическая культура (Талицкий, 1951, с. 4-58). В 2016 году в связи с аварийным состоянием памятника раскопки были возобновлены и по настоящее время проводятся под руководством А.Н. Сарапулова. За все годы полевых археологических изысканий на памятнике изучено более 1000 кв. м.

В сохранившейся предвальной части памятника, исследуемой в последние годы, были выявлены и изучены объекты, в пределах которых была зафиксирована серия очагов, производственных и углежогных ям, остатки каменного горна, а в их культурном слое в массовом количестве были обнаружены бракованные и недоработанные изделия, следы производства и сырье (шлаки, литники, сплески металла, металлический лом, серебряные, латунные, бронзовые, свинцово-оловянные слитки и т. д.), а также разный универсальный и специализированный инструментарий (фрагменты форм-изложниц, глиняных и каменных литейных форм, фрагменты цилиндрических тиглей и т. д.). Обнаружение данных артефактов позволило интерпретировать объекты как литейные и ювелирные мастерские, функционировавшие в XI - начале XII вв.

Одними из наиболее значимых находок, обнаруженных в пределах мастерских, стали куски необработанного янтаря-сырца (рис. 1: 1). Несмотря на то, что их количество невелико - всего 14 экземпляров (общий вес 39 грамм), в настоящий момент находки необработанного янтаря-сырца в средневековых материалах являются самой северо-восточной находкой и в археологических памятниках Пермского Предуралья обнаружены впервые.

Найденные образцы янтаря имеют небольшие размеры (от 8 до 29 мм в длину), вес (от
0,5 до 3,33 г) и форму в виде капель, отдельных фрагментов наствольных натеков. На образцах фиксируется корочка выветривания в виде неровной и шероховатой поверхности, в одном случае - с вкраплениями органического материала. Степень прозрачности янтаря разная - имеются образцы прозрачного янтаря без внутренних пустот, полупрозрачного с внутренними полостями и костяного, напоминающего слоновую кость. Различаются образцы и по цвету - от яркого желто-оранжевого до коричнево-красного. Большинство образцов отличаются хрупкостью и обильным наличием микротрещин внутри (рис. 1:2).

Также был обнаружен и поврежденный (со следами скола) фрагмент янтаря правильной формы в виде параллелепипеда (ширина и длина 11,5 мм, высота 3,5-4 мм). Его правильная форма, наличие явных следов обработки и отсутствие на поверхности корочки выветривания позволили отнести данный образец к уже готовой, но отбракованной вставки в каст будущего ювелирного изделия (рис. 1: 3).

Находки практически всех фрагментов янтаря были сконцентрированы в слое производственных ям (яма 6/2019 года раскопок, яма 1/2020 года раскопок) в пределах мастерских, где было налажено наряду с бронзолитейным производством и изготовление ювелирных изделий - здесь были обнаружены достаточно крупные сплески серебра (Ag более 90\%), крупный серебряный слиток $(84,68$ г), (рис. 2 : $3)$, серебряная гривна глазовского типа позднего варианта (Ag более 90\%, 190 г) (рис. 2: 1), однобусинное зерно-филигранное височное украшение (Ag более 90\%) (рис. 2: 4), недоделанный зерно-филигранный медальон с предполагаемой вставкой (Ag более 90 \%, на изделии отсутствуют следы пайки петли для крепления, а также не вставлена вставка в каст на изделии и т. д. (рис. 2: 2), спаянная пирамидка крупной зерни ( $\mathrm{Ag}$ более 90\%) и т. д. ${ }^{1}$ Возможно, обнаруженная янтарная вставка квадратной формы была изготовлена именно для зерно-филигранного медальона округлой формы, но ввиду появлявшихся частых сколов при обработке янтаря была забракована мастером.

Небольшое количество янтаря-сырца в пределах мастерских, обнаружение готовой отбракованной вставки, а также недоработанного украшения с не вставленной вставкой в каст изделия могут указывать на то, что кусковой янтарь поступал к мастерам Роданова городища для ювелирных нужд, а именно для изготовления вставок в ювелирные изде- 

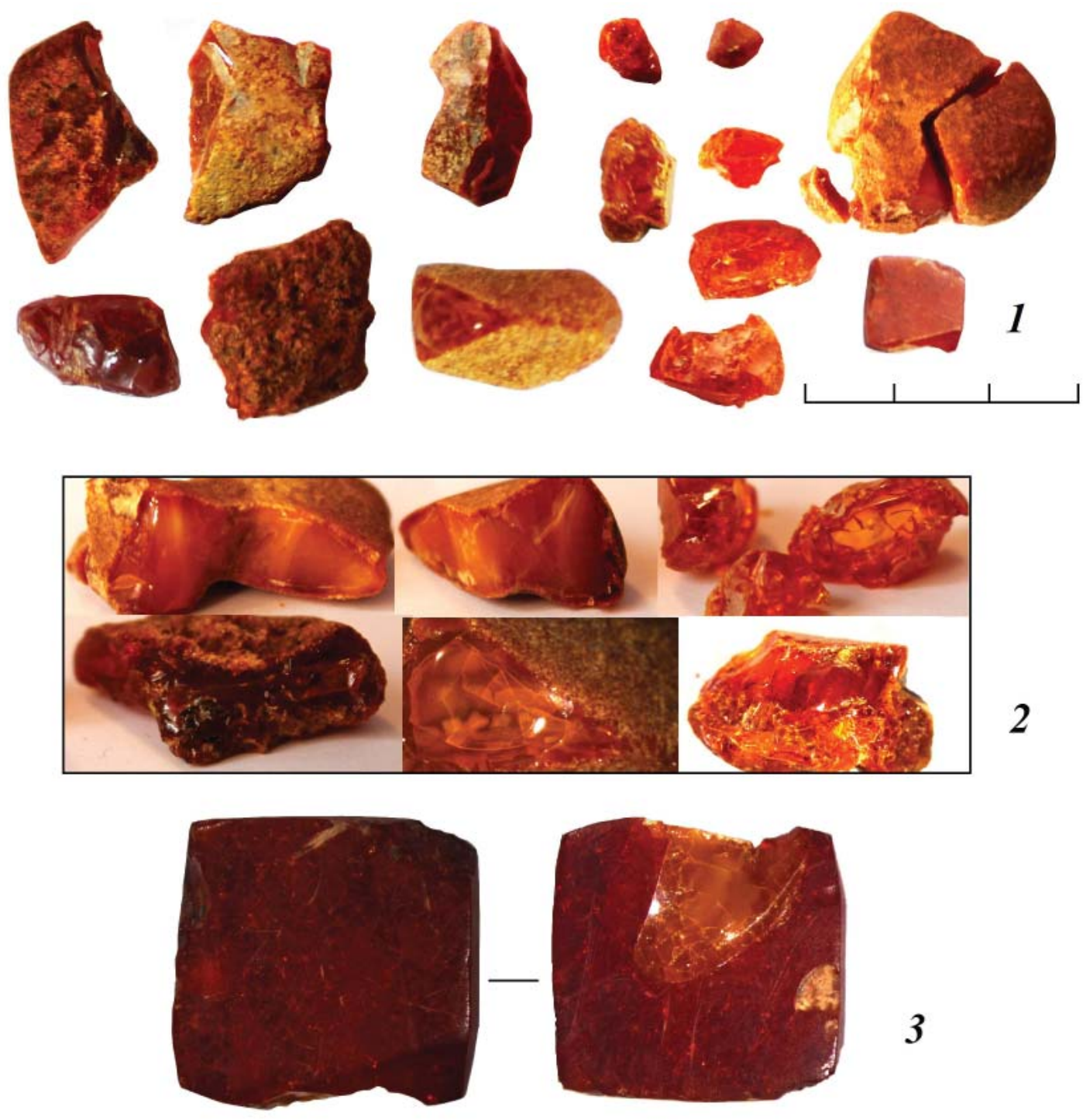

Рис. 1. Янтарь из культурного слоя Роданово городища: 1 - обнаруженные куски янтаря и предполагаемая вставка, 2 - цвет и прозрачность янтаря; 3 - обработанная и забракованная вставка из янтаря

Fig. 1. Amber from the cultural layer of Rodanovo hillfort: 1 - discovered pieces of amber and a supposed insert, 2 - color and transparency of amber; 3 - processed and rejected amber insert.

лия. Вполне возможно и то, что данный необработанный янтарь мог быть оставленным за ненадобностью и отбракованным мастерамиювелирами материалом, так как хрупкость найденных образцов, наличие внутри них многочисленных трещин не позволяли обрабатывать его до необходимых форм.

Для территории Пермского Предуралья традиция декорирования ювелирных изделий вставками из разных материалов (стекло, камень, янтарь) характерна для периода c IX (возможно, конца IX в.) по XIII вв., то есть в то время, когда в регионе развивается собственное ювелирное ремесло, имеющее свои характерные стилистические и технологические особенности. В X - первой половине XI вв. распространены характерные только для прикамской территории перстни-колпачки, украшенные зерно-филигранным декором и кастами с вставками из разных материалов (Моряхина, 2015, с. 163-167). В IX - первой половине X вв. были распространены ножны в серебряных обкладках, украшенные зернофилигранным декором и кастами с вставками из разных материалов (Подосёнова, 2018a, с. 199-204). В период конца Х-XIII вв. кастами с вставками из разных материалов и зернофилигранным декором украшаются калачевидные височные украшения (Подосёнова, 2017 , с. 38-44), арочные шумящие подвески и флаконовидные пронизки (Головчанский, Мельничук, Скорнякова, 2013, с. 133-143), трапециевидные подвески (Подосёнова, 2018б, с. 187-191), медальоны круглой и 


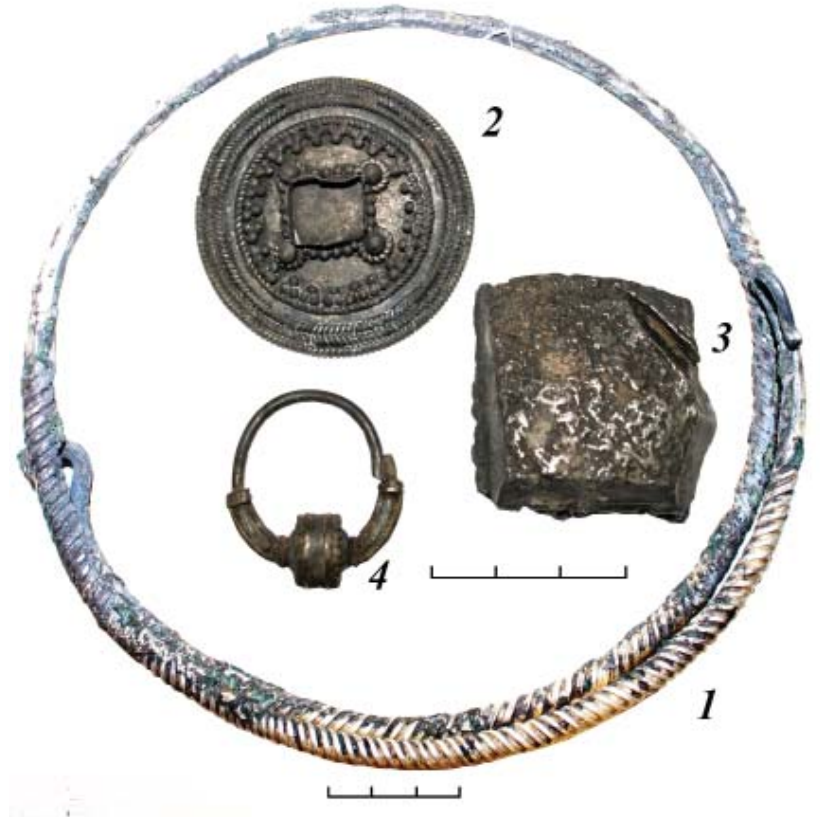

ромбической формы (Крыласова, Подосёнова 2019, с. 86-93) и т. д.

Вставки прикамских ювелирных изделий выполнены из разных материалов - поделочных каменей (сердолика, горного хрусталя и камней неопределенных пород), кусочков стекла или стеклянных бусин, смолы и янтаря.

Целенаправленное исследование материала, из которого были изготовлены вставки в ювелирные изделия, только начинается (включая геммологические определения), поэтому в настоящий момент трудно обозначить количество прикамских украшений с вставками из обработанного янтаря, однако возможно выделить хронологические рамки его использования прикамскими мастерамиювелирами - IX-XII вв.

Вставки из янтаря в ювелирных изделиях представлены разными формами - квадратной и прямоугольной (параллелепипеда), овальной (призматической) и каплевидной, а также в виде простых кабошонов (имеющих одну плоскую поверхность, а другую - выпуклую). Изготовленная вставка вставлялась в специально подготовленный глухой каст, изготовленный из полоски металла, согнутой по форме вставки и припаянной на металлическую основу изделия. Вставка крепилась способом заваливания его краёв. Дополнительно вставка могла подклеиваться на основу изделия веществом, напоминающим смолу.

Необходимо отметить, что бусы и амулеты, выполненные из янтаря, не пользовались особой популярностью у населения Пермского Предуралья, они встречаются в материалах памятников разных периодов эпохи Средневековья, но немногочисленно (бусы)
Рис. 2. Отдельные изделия из серебра, обнаруженные в пределах мастерских: 1 - гривна глазовского типа,

2 - шейно-нагрудное украшение, 3 - слиток, 4 - однобусинное височное украшение

Fig. 2. Individual silver items found in the workshops:

1 - Glazov-type gryvna, 2 - neck-chest decoration,

3 - ingot, 4 - single-bead temporal decoration

или единично (амулеты) и, вероятнее всего, являются привозными.

Изготовление из янтаря-сырца вставок не представляло каких-либо определенных сложностей. Стадии обработки янтаря описаны и разобраны на материалах ремесленных мастерских Великого Новгорода (Розенфельдт, 1978, с. 200; Шаповалов, 1998, с. 109-120). Для изготовления вставок в касты ювелирных изделий мастера-ювелиры использовали следующие операции:

1) сортировка янтаря-сырца по цвету и качеству;

2) очищение выбранного образца от «корочки» выветривания с помощью абразивных инструментов или материалов;

3) обточка заготовки до нужной формы;

4) шлифовка образца;

5) полировка полученного образца;

6) возможно, для отдельных вставок использовалась термическая обработка (прокаливание) образца для изменения его цвета.

Иногда поверхностная корочка выветривания на лицевой стороне образца не снималась, и вставки имели матовую, шероховатую поверхность.

В рамках этого интересна следующая наблюдаемая особенность во вставках ювелирных изделий. Сердоликовые вставки в ювелирных изделиях практически всегда представлены в виде расколотых или целых сердоликовых бусин, на сегодняшний день специальные вставки из обработанного сердолика в прикамских ювелирных изделиях практически отсутствуют. Это может свидетельствовать о том, что прикамские мастера владели простыми навыками обработки только легко поддающегося обработке материала, каким и являлся янтарь.

С целью решения вопроса о месте происхождения янтаря было проведено исследование по его идентификации.

Для анализа, идентификации и установления сравнительных характеристик было отобрано несколько археологических образцов (шифры ANS), обнаруженных при раскопках, а также балтийский янтарь (шифры OYU и МР), отобранный в районе Куршской косы в июле 2017 года. Все вышеуказанные образ- 
цы представлены в виде разновидностей: прозрачной (от светло-желтого до темнокоричневого цвета), замутненной (медовожелтого цвета) и костяной (белого цвета со слабым желтоватым оттенком).

Кроме того, представляло интерес проверить идею об искусственном происхождении янтареподобных артефактов в культурном слое. Для этого был проанализирован образец свежей сосновой смолы и сосновой канифоли (ГОСТ 19113-84).

Пробоподготовка проводилась в соответствии с протоколами работы на аналитических приборах и особенностями самих образцов. Исследования проводились с помощью современных инструментальных методов на базе Лаборатории термических методов анализа Пермского государственного национального исследовательского университета (аналитики Мокрушин И.Г., Красновских М.П., Иванов П.А., Каменщиков О.Ю.). Были проведены исследования следующими методами:

- синхронным термическим анализом (CTA);

- методом инфракрасной спектроскопии (ИК);

- методом сканирующей электронной микроскопии (СЭМ) с приставкой для локаль- ного микрорентгеноспектрального анализа (РФлА);

- анализ микротвердости на базе моторизованного микротвердомера;

- исследование на газовом хроматографе с масс-спектрометрическим детектором (ГХ-MC).

При исследовании данных артефактов разными методами были получены следующие результаты:

Синхронный термический анализ. Суть метода заключается в исследовании воздействия тепла на ископаемые смолы (Фракей, 1990 , с 172). По итогам исследования установлено, что термическое поведение археологических образцов и образцов прибалтийского янтаря идентично. Основные этапы потери массы и наблюдаемые термические эффекты образцов ANS и MP наблюдаются в схожих температурных диапазонах и совпадают с описанными ранее в научных публикациях (Мартиросян, Богдасаров, 2011, с. 10-15).

На кривых термического анализа (рис. 3, 4) образцов ANS и MP фиксируются стадии плавной потери веса $35-280^{\circ} \mathrm{C}$ за счет испарения низкомолекулярных продуктов, экзотермические фазы предварительного окисления $\left(280-350^{\circ} \mathrm{C}\right)$ и основного окислительного

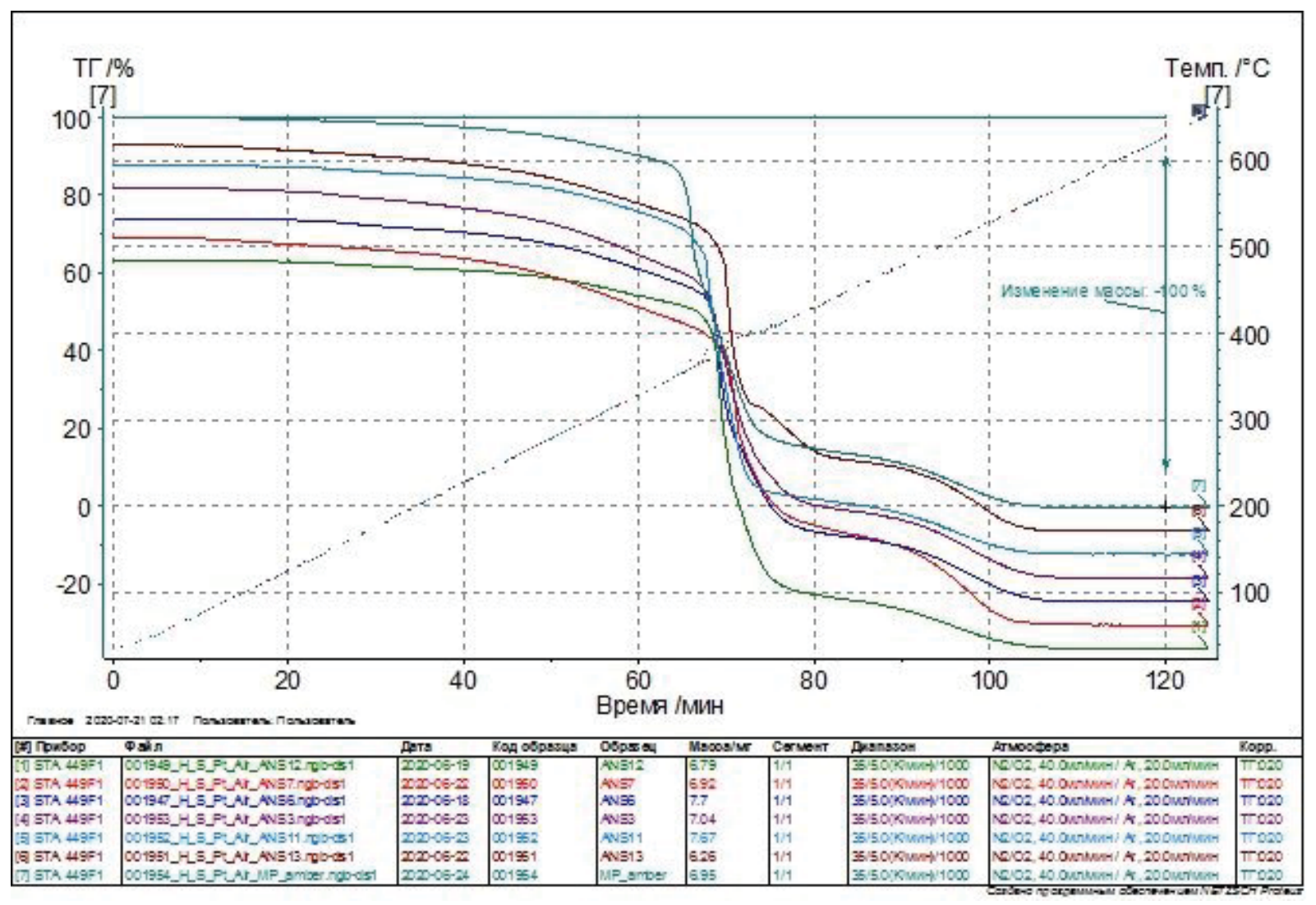

Рис. 3. Кривые потери веса (ТГ) археологических образцов ANS и образца сравнения MP

Fig. 3. Weight loss curves (TG) of ANS archaeological specimen and MP comparison specimen 


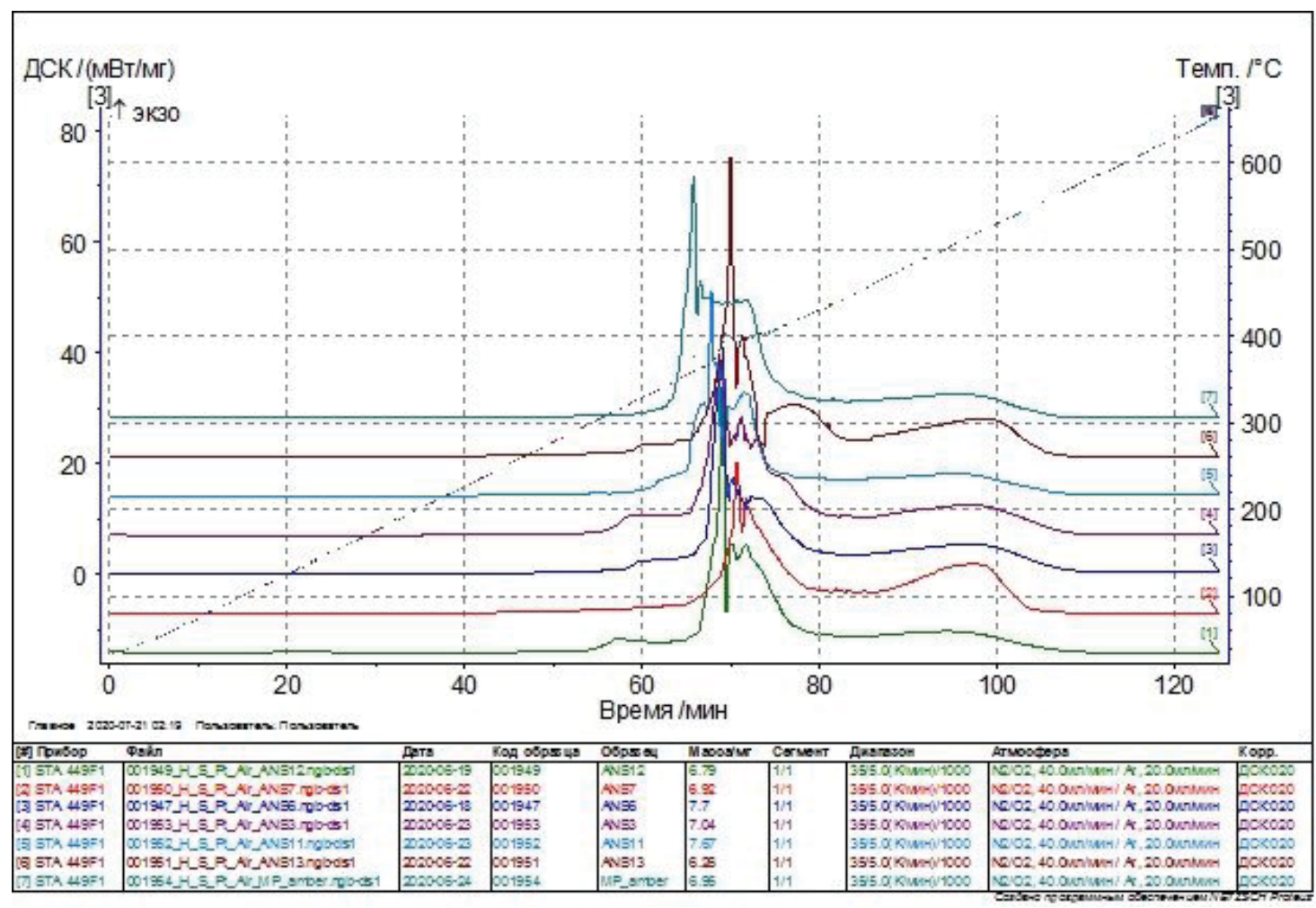

Рис. 4. Тепловые кривые (ДСК) археологических образцов ANS и образца сравнения MP

Fig. 4. Thermal curves (DSC) of ANS archaeological specimens and MP comparison specimen

пиролиза образца $\left(350-430^{\circ} \mathrm{C}\right)$ с образованием коксового остатка и его дальнейшее догорание в интервале $430-700^{\circ} \mathrm{C}$.
Интересно сравнить ход термоокислительной деструкции свежей смолы, канифоли и янтаря. Фиксируется то, что по мере «старения» образца снижается содержание низко-

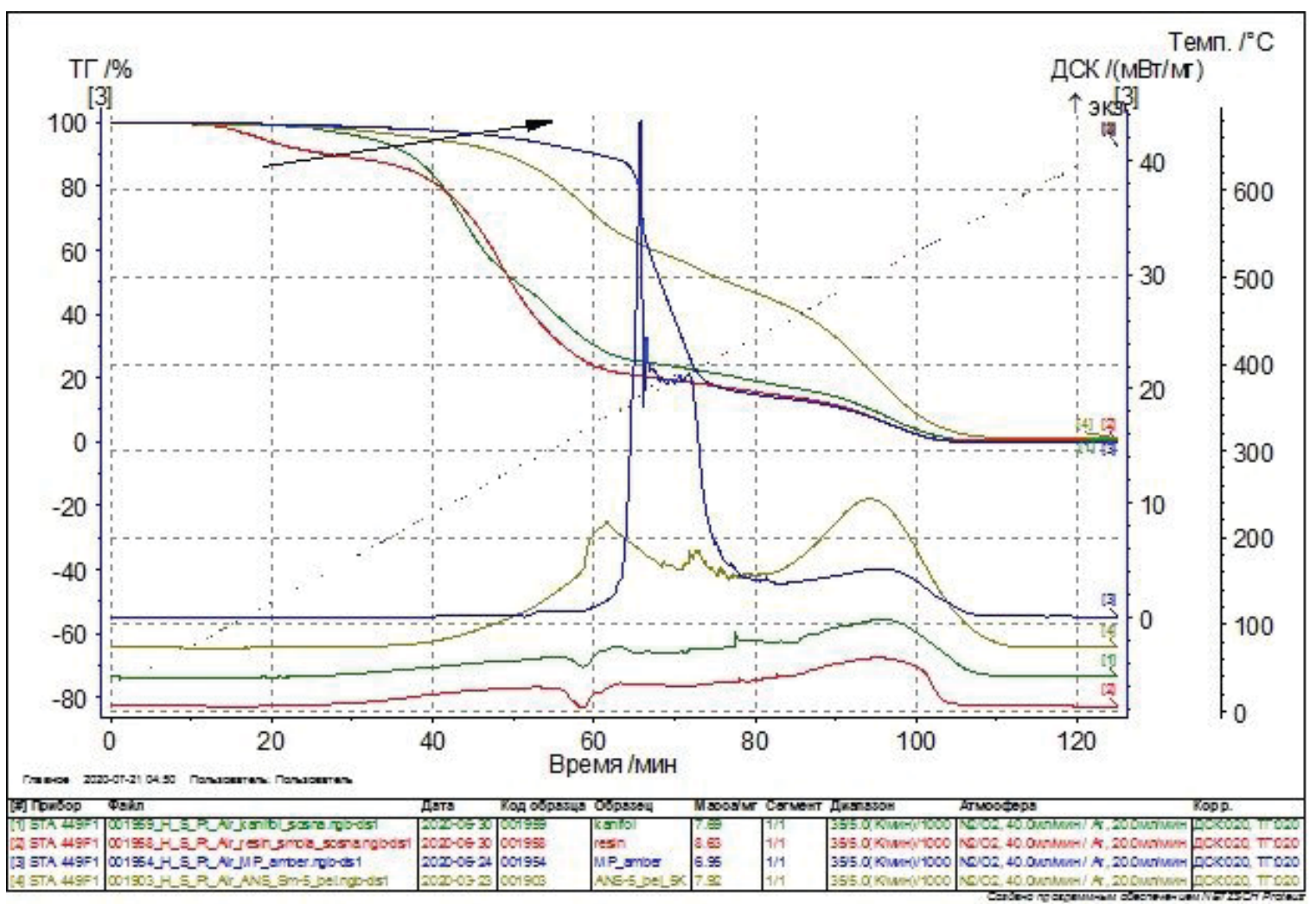

Рис. 5. Результаты синхронного термического анализа свежей сосновой смолы, канифоли, неизменного костяного янтаря и образца сравнения МР

Fig. 5. Simultaneous thermal analysis results for fresh pine resin, rosin, unchanged bone amber, and MP comparison sample 
молекулярных (сравнительно низкокипящих) соединений и кривая ТГ сдвигается вправо, формируется более выраженный экзотермический эффект окисления в интервалах 250-420 ${ }^{\circ} \mathrm{C}$ (рис. 5). По-видимому, на результат СТА анализа в значительной степени влияют также условия формирования природного янтаря. Находки из культурного слоя, таким образом, могут быть идентифицированы как янтарь.

Метод инфракрасной спектроскопии. Суть метода заключается в том, что вещества любого типа можно идентифицировать по их способности поглощать световую энергию инфракрасного излучения. Получающийся спектр поглощения позволяет произвести количественный анализ сложных соединений, определить примеси и установить атомную структуру молекул. Образцы янтаря разного возраста или с разных месторождений обычно имеют характерные спектры. Одинаковые спектры могут характеризовать янтарь с конкретного месторождения (Фракей, 1990, с 169). Уникальной особенностью балтийского сукцинита (балтийского янтаря) является так называемый «балтийский зубец» - широкая горизонтальная площадка в диапазоне от 1250 до $1195\left(\mathrm{~cm}^{-1}\right)$, сопровождаемая острым пиком, достигающим максимальной интенсивности в $\sim 1160 \mathrm{~cm}^{-1}$, после которого поглощение быстро уменьшается (Мартиросян, Богдасаров, 2011, с. 10-15). ИК-спектры поглощения получены для «таблеток» с бромидом калия и представлены (рис. 6, 7). Характерный «балтийский зубец» был зафиксирован как в образцах балтийского янтаря, так и в образцах из слоя городища (рис. 6), в то время как образцы смолы и канифоли имеют более разнообразный состав, характерного вида линий «балтийского зубца» не зафиксировано (рис. 7).

По аналогии с СТА анализом в результате ИК-спектроскопии обнаружилось, что по мере «старения» образца уменьшается группа линий 1200-1290 см$^{-1}$ при сохранении интенсивности линии $1160 \mathrm{~cm}^{-1}$, что может вести к формированию вида «балтийского зубца».

Метод сканирующей электронной микроскопии (СЭМ) с приставкой для локального микрорентгеноспектрального анализа (РФлА). Суть метода заключается в исследовании химического состава образца или исследовании определенного элемента и его содержания в химическом составе образца. Химический состав янтаря сложен и изменчив в зависимости от территорий происхождения. Как отмечают исследователи, в химическом составе янтаря есть элементы, проявляющиеся в определенном содержании, которые могут являться признаками для идентификации его места происхождения. Среди таких элементов-признаков выделяют серу с её определенным количественным содержанием (например, янтари Украины содержат до 3,19\% серы, а янтари Румынии до 1,4\%). (Сребродольский, 1984; Фракей, 1990, с. 133).

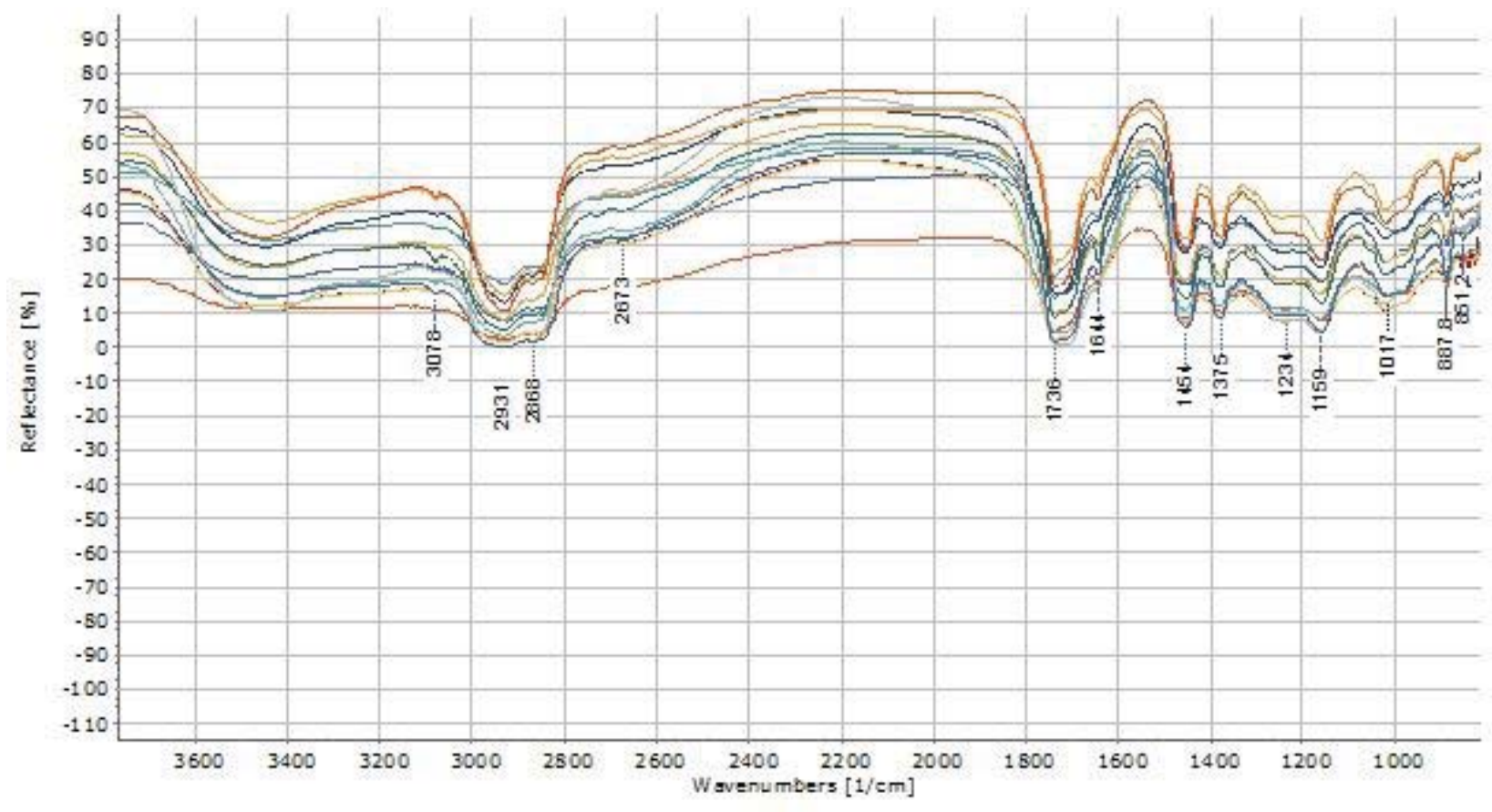

Рис. 6. ИК спектры образцов ANS с характерным видом линий поглощения в области 1100-1350 $\mathrm{cm}^{-1}$ Fig. 6. IR spectra of ANS samples with characteristic absorption lines in the range of $1100-1350 \mathrm{~cm}^{-1}$ 


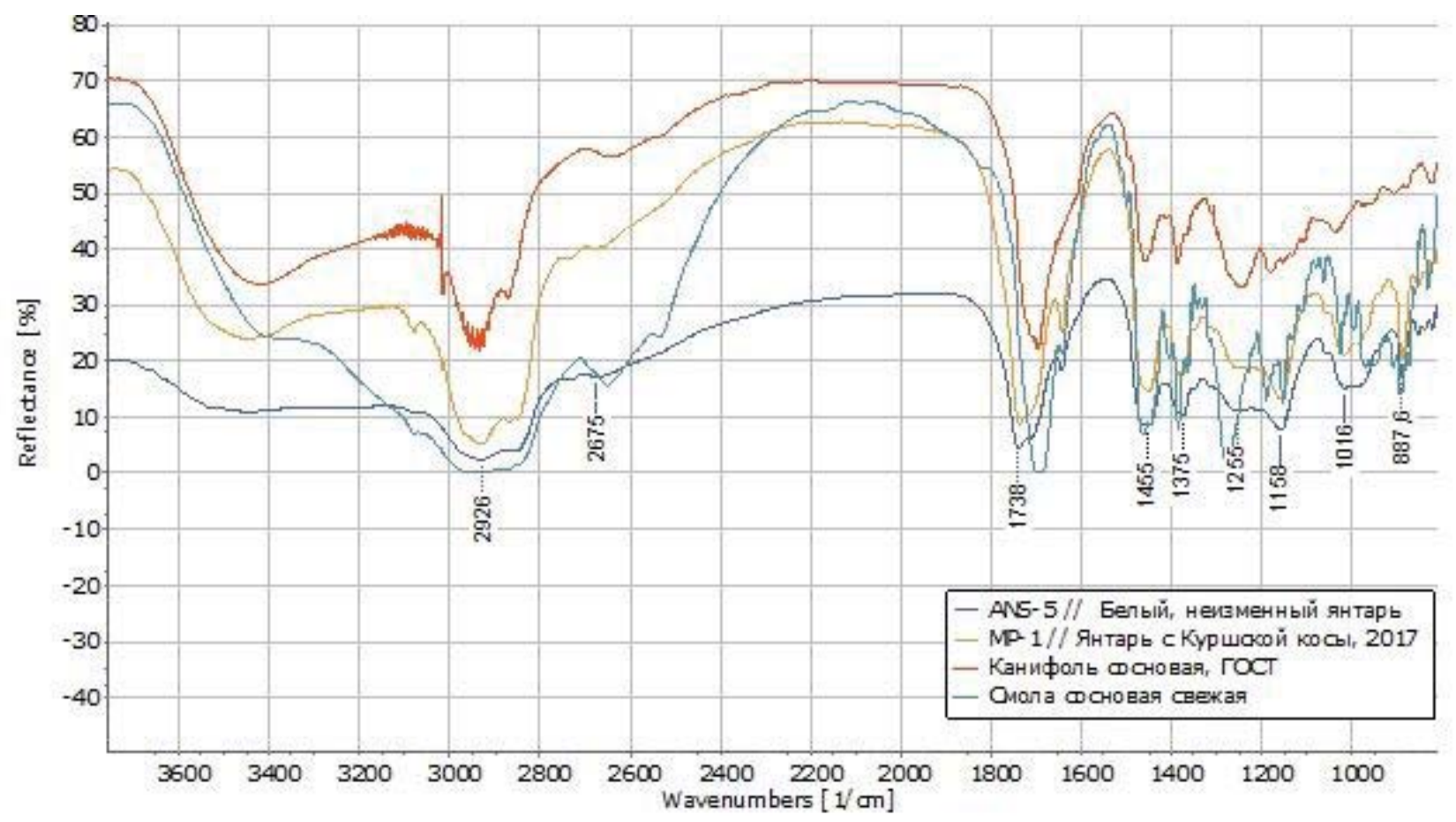

Рис. 7. Результаты инфракрасной спектроскопии свежей сосновой смолы, канифоли, неизменного костяного янтаря и образца сравнения МР

Fig. 7. Infrared spectroscopy results for fresh pine resin, rosin, immutable bone amber, and MP comparison sample

Для балтийского сукцинита (янтаря) характерен следующий основной элементный состав (в \%): углерод - 76,7; водород - 10,1-10,5; азот и сера - до 0,55; кислород - 7,9-12,9 (Сребродольский, 1988).

В анализируемых образцах было исследовано количественное содержание серы (табл. 1). Содержание серы в исследуемых образцах близко к основным показателям, представленным исследователями балтийского сукцинита ранее (исследования Б.И. Сребродольского).

Анализ микротвердости на базе моторизованного микротвердомера. Суть данного анализа заключается в исследовании микротвердости образцов. В геммологии данный анализ помогает идентифицировать драгоценные, полудрагоценные и поделочные камни, смолы.

Янтарь относится к мягким органическим материалам. Согласно данным (Савкевич, 1970), «абсолютная» величина твердости балтийского янтаря колеблется в довольно

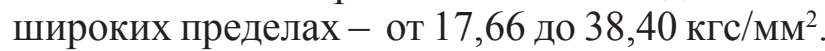

При исследовании проводились определения микротвердости рассматриваемых нами образцов по методу Виккерса (табл. 1, приведено среднее значение измерений в 5 точках). Твердость исследованных образцов варьиру-

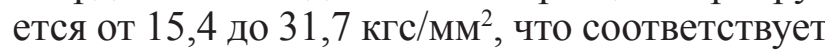
вышеуказанному интервалу значений и позволяет отнести исследуемые образцы также к балтийскому янтарю.
Исследование экстракта на газовом хроматографе с масс-спектрометрическим детектором (ГХ-МС). Суть метода заключается в первоначальном разделении исходной сложной смеси на компоненты с последующим анализом с помощью масс-спектрометра.

В научной литературе термин «балтийский янтарь», или сукцинит, обычно относят к смолам, выделяющим янтарную кислоту. Балтийский янтарь, или сукцинит, содержит от 3 до 8\% янтарной кислоты (Фракей, 1990, c. 12-13). Наличие её производных при исследовании разных ископаемых и неископаемых смол является доказательством того, что образец может быть отнесен к определенному виду янтаря (Poulin, Helwig, 2014). Такие производные были зафиксированы нами для балтийского янтаря Куршской косы и некоторых образцов из культурного слоя.

Таким образом, полученные результаты инфракрасной спектрометрии, синхронного термического анализа, определения твёрдости и содержания серы позволяют идентифицировать артефакты из мастерских Роданова городища как образцы кускового янтаря балтийского происхождения.

На вопрос о том, какими путями попадал прибалтийский кусковой необработанный янтарь в прикамские ювелирные мастерские однозначно ответить трудно. В рассматриваемый период времени в большом количестве прибалтийский янтарь-сырец был обнаружен 
Таблица 1. Характеристики образцов: содержание серы, микротвердость, «балтийский зубец» Table 1. Sample characteristics: sulfur content, microhardness, "Baltic tooth".

\begin{tabular}{|l|c|c|c|}
\hline Образец & $\begin{array}{c}\text { Содержание } \\
\text { серы, (\% вес) }\end{array}$ & $\begin{array}{c}\text { Усредненное значение } \\
\text { микротвердости, кгс/мм }\end{array}$ & $\begin{array}{c}\text { Наличие } \\
\text { «балтийского зубца» } \\
\text { на ИК спектре }\end{array}$ \\
\hline MP1 & 0,61 & 26,93 & Есть \\
\hline MP2 & - & 21,30 & Есть \\
\hline OYU & - & 19,17 & Есть \\
\hline ANS3 & не обнаружена & 24,96 & Есть \\
\hline $\begin{array}{l}\text { ANS5 (прозрачный, желтый, } \\
\text { «окисленная пленка») }\end{array}$ & 0,61 & - & Есть \\
\hline $\begin{array}{l}\text { ANS5 (белый, непрозрачный, } \\
\text { «неизменный янтарь») }\end{array}$ & 0,57 & 24,20 & Есть \\
\hline ANS6 & 0,65 & 31,73 & Есть \\
\hline ANS7 & не обнаружена & 15,4 & Есть \\
\hline ANS10 & 0,57 & - & Есть \\
\hline ANS11 белый & 1,1 & 18,88 & Есть \\
\hline ANS11 прозрачный & 0,21 & 17,48 & Есть \\
\hline ANS12 & 0,82 & 18,84 & Есть \\
\hline ANS13 & 0,32 & - & Нет \\
\hline Смола сосновая свежая & 0,97 & мягкая & Нет \\
\hline Канифоль сосновая (ГОСТ 19113-84) & не обнаружена & 10,36 & \\
\hline
\end{tabular}

на соседней с Пермским Предуральем территории Волжской Булгарии в пределах «мастерской» по обработке янтаря в Биляре (около 9 кг) (Хузин, Валиуллина, 1986, с. 97-116). В последнее время на основании небольшого количества изделий из этого материала и отсутствия заготовок исследователи видят в данном комплексе янтарных находок скорее склад сырья, чем мастерскую по его обработке (Бадеев, Гареев, Баталин, 2019, с. 239), и появление янтаря-сырца на булгарской территории связывается с деятельностью выходцев из древнерусских территорий (Бадеев, Гареев, Баталин, 2019, с. 243).

В период X-XII вв. территория Пермского Предуралья находилась в сфере политических и экономических интересов волжских булгар. Множество фактов свидетельствует о пребывании и даже долговременном проживании булгарских купцов и ремесленников на крупных ломоватовско-родановских городищах (Белавин, Крыласова 2008). Не исключением было и Роданово городище, в материалах которого также встречаются изделия булгарского происхождения, а также керамика.

Однако основной массив привозных изделий, обнаруженных в материалах городища, составляют изделия, происхождение которых можно связать с древнерусскими территориями (кресты-тельники с выемчатой эмалью, отдельные типы гребней и расчесок, костяная флейта, гирька скандинавского типа, овручские пряслица, фрагмент булавы киевского типа и т. д.) (Сарапулов, Подосенова, Каменщиков, Мокрушин, 2020, с. 21-27; Шмырина, 2020 , с. 122-130). Возможно, и янтарь-сырец мог попасть с территорий древнерусских городов, при исследовании которых выделяются не только домонгольские мастерские по обработке янтаря-сырца, но и постройки с большими запасами янтаря, предназначенного для перепродажи. В качестве примера можно привести находки янтаря во Владимире (Зеленцова, Кузина, Милованов, Черненко, 2011, с. 75-81; Зеленцова, Кузина, Милованов, 2009, с. 45-47). Приток разнообразных изделий древнерусского происхождения на территорию Пермского Предуралья начинается с XI века и концентрируется в основном в его северной части и в бассейне р. Иньвы (Белавин, Крыласова, 2017, с. 284-285), что может свидетельствовать о северо-западном пути проникновения древнерусского материала вдоль Сухоно-Вычегодского водного пути, берущего свое начало от Ладожского Озера и протянувшегося до Уральского хребта (Археология Республики Коми, 1997, с. 657), что также неоднократно было представлено в археологических работах (Головчанский, Мельничук, 2018, с. 103).

Однако каким бы ни был путь поступления янтаря-сырца на территорию Пермского Предуралья, возникает другой вопрос - каким образом в исходные древнерусские мастерские по переработке янтаря или сооружения-склады янтаря-сырца в XII-XIII вв. ввозится янтарь- 
сырец прибалтийского происхождения. В последнее время в археологической литературе считается, что в домонгольский период на территории Руси преобладало использование янтаря приднепровского происхождения (Рыбина, 2001, с. 71-77). Однако еще в 80-х гг. XX века исследователями предполагалось, что в домонгольский период применялся прибалтийский янтарь, так как разработка приднепровских месторождений янтаря активно не производилась (Розенфельдт, 1978, с. 197). Возможно, в будущем точная естественнонаучная идентификация янтаря с древнерусских археологических памятников позволит ответить на этот вопрос.

\section{Примечание:}

${ }^{1}$ Публикация, посвященная результатам исследования ювелирных и бронзолитейных мастерских Роданово городища находится в печати

\section{ЛИТЕРАТУРА}

Археология республики Коми / Отв. ред. Э. А. Савельева. М.: ДиК, 1997. 756 с.

Бадеев Д.Ю., Гареев Б.И., Баталин Г.А. Мастерская по обработке янтаря с территории Золотоордынского Болгара // КСИА. 2019. Вып. 257. С. 232-246.

Белавин А.М., Крыласова Н.Б. Древняя Афкула: археологический комплекс у с. Рождественск. Пермь: Перм. гос. пед. ун-т., 2008. 603 с.

Белавин А.М., Крыласова Н.Б. Древнерусские материалы в Пермском Предуралье в X-XI вв. // Поволжская археология. 2017. № 1 (19). С. 284-297.

Головчанский Г.П., Мельничук А.Ф., Скорнякова С.В. Лёкмартовский клад средневековых изделий из Северного Прикамья // Культурные связи населения европейского северо-востока в древности и в средневековье / МАЕСВ. Вып. 18 / Отв. ред. .О. И. Васкул Сыктывкар: ИЯЛиИ Коми НЦ УрО РАН. 2013. C. 133-143.

Головчанский Г.П., Мельничук А.Ф. Христианская символика в археологических древностях эпохи средневековья в Пермском Приуралье // Вестник Пермского университета. История. 2018. Вып. 1 (40). C. $101-111$.

Зеленцова О.В., Кузина И.Н., Милованов С.И., Черненко В.В. Янтарь из раскопок древнейшей части Владимира-на Клязьме // Балтийский янтарь: наука. Культура. Экономика: материалы международного научного симпозиума «Добыча и обработка янтаря на Самбии» / Под. Ред. З.В. Костяшова. Калининград: Калининградский музей янтаря. 2011. С. 75-81.

Зелениова О.В., Кузина И.Н., Милованов С.И. Склад янтаря-сырца во Владимире // Природа. 2009. Вып. 8 (1128). С. 45-47.

Крыласова Н.Б., Подосёнова Ю.А. Ромбическая ювелирная подвеска из Рождественского городища // Вестник Музея археологии и этнографии Пермского Предуралья. 2019. Вып. IX. C. 86-93.

Мартиросян O.В., Богдасаров М.A. Ископаемые смолы: диагностика, классификация и структурные преобразования в условиях термального воздействия // Вестник Института геологии Коми НЦ УрО PAH. 2014. №4. C. 10-15.

Моряхина К.В. Перстни-«колпачки с территории Пермского Предуралья // Труды Камской археолого-этнографической экспедиции. Вып. X / Ред. Н.Б. Крыласова. Пермь: Перм. гос. гуманит.-пед. ун-т, 2015. С. 163-167.

Отчет Н.А. Прокошева об археологических работах на строительстве Камской ГЭС в 1935 г. на Каме и Чусовой по Открытому листу № 42 / Рукописный архив ИИМК РАН. Ф. 2, дело № 29.

Подосёнова Ю.А. Калачевидные височные украшения на территории Пермского Предуралья в период средневековья // Вестник Музея археологии и этнографии пермского Предуралья, 2017. Вып VII. C. 38-44.

Подосёнова Ю.А. Ножны в серебряных обкладках с филигранным и зерневым декором из Баяновского могильника ломоватовской археологической культуры // Труды Камской археолого-этнографической экспедиции. Вып. XIV. / Под ред. А.М. Белавина. Пермь: ПГГПУ, 2018. С. 199-204. 
Подосёнова Ю.А. Скано-зерневые трапециевидные подвески с территории Предуралья и Зауралья (родановская, чепецкая, вымская археологические культуры и Приобье) // Человек и север: антропология, археология и экология: материалы всероссийской научной конференции. Вып. 4. / Отв. ред. А.Н. Багашев. Тюмень: ФГБУН ФИЦ ТюмНЦ СО РАН. 2018б. С. 187-191.

Разведочные работы А.В. Шмидта на Пермской платине Средне-Волгостроя (переписка и отчеты) / Рукописный архив ИИМК РАН. Ф. 2, ар. № 127, дело № 8, 1932 г.

Розенфельдт Р.Л. Янтарь на Руси (Х-XIII вв.) // Проблемы советской археологии /Отв. ред. В.В. Кропоткин и др. М.: Наука. 1978. С. 197-208.

Рыбина E.A. Торговля средневекового Новгорода. Новгород: Новгородский государственный университет им. Ярослава Мудрого. 2001. 390 с.

Савкевич С.С. Янтарь. Ленинград: Недра, 1970. 192 с.

Сарапулов А.Н., Подосенова Ю.А., Каменщиков О.Ю., Мокрушин И.Г. Находки средневековых крестов на Родановом городище Пермского края // Труды Камской археолого-этнографической экспедиции. Вып.XVI. / Отв. ред. А.М. Белавин. Пермь: ПГГПУ, 2020. С. 21-27.

Спицын А.А. Древности Камской Чуди по коллекции Теплоуховых / МАР. № 26. СПб., 1892 г.

Сребродольский Б.И. Янтарь. М.: Наука, 1984. 109 с.

Сребродольский Б.И. Мир янтаря. Киев: Наукова думка, 1988. 141 с.

Талиџкий М.В. Отчет по обследованию археологических памятников бассейна р. Иньвы (правый приток Камы) Кудымкарского округа Пермской области / Рукописный архив ИИМК РАН Ф. 35, д.71.

Талицкий М.В. Верхнее Прикамье в X-XIV вв. // МИА. № 22 / Отв. ред. В.Н. Чернецов. М.: АН CCCP, 1951. C. 4-58.

Шаповалов Р.Г. Обработка янтаря в средневековом Новгороде // Новгород и Новгородская земля. История и археология. Вып.12. / сост. П.Г. Гайдуков, Т.Н. Казармщикова. Новгород: Новгородский государственный объединенный музей-заповедник. 1998. С. 109-120.

Фракей Э. Янтарь. М.: Мир, 1990. 198 с.

Хузин Ф.Ш., Валиуллина С.И. Славяно-русские материалы в Биляре // Волжская Булгария и Русь (к 1000-летию русско-булгарского договора) / Отв. ред. А.Х. Халиков. Казань: ИЯЛИ КФ АН СССР. 1986. C. 97-116.

Шмырина М.Е. Проблема импорта костяных изделий в эпоху средневековья на территории Пермского Предуралья (на примере Иньвенской группы памятников) // Труды Камской археолого-этнографической экспедиции. Вып. XVII. / Отв. ред. А.М. Белавин. Пермь: ПГГПУ, 2020. С. 122-130.

Poulin, J. and Helwig, K. 'Inside Amber: The Structural Role of Succinic Acid in Class Ia and Class Id Resinite'. (2014).

\section{Информация об авторах:}

Сарапулов Алексей Николаевич, кандидат исторических наук, доцент, заведующий кафедрой, Пермский государственный гуманитарно-педагогический университет (г. Пермь, Россия); ans05@mail.ru

Мокрушин Иван Геннадьевич, кандидат химических наук, доцент, Пермский государственный национальный исследовательский университет (г. Пермь, Россия); mig@psu.ru

Красновских Мария Павловна, заведующая Лабораторией, Пермский государственный национальный исследовательский университет (г. Пермь, Россия); krasnovskih@yandex.ru

Иванов Петр Алексеевич, студент, Пермский государственный национальный исследовательский университет (г. Пермь, Россия); zukk33@gmail.com

Каменщиков Олег Юрьевич, заведующий Лабораторией, Пермский государственный национальный исследовательский университет (г. Пермь, Россия); koy@chemanalysis.ru

Подосенова Юлия Александровна, кандидат исторических наук, старший научный сотрудник, доцент, Пермский федеральный исследовательский центр УрО РАН, Пермский государственный гуманитарно-педагогический университет (г. Пермь, Россия);podosenka@yandex.ru

\section{REFERENCES}

Savel'eva, E. A. (ed.). 1997. Arkheologiia Respubliki Komi (Archaeology of the Komi Republic). Moscow: "DiK" Publ. (in Russian).

Badeev, D. Yu.. Gareev, B. I., Baalin, G. A. 2019. In Kratkie soobshcheniia Instituta arkheologii (Brief Communications of the Institute of Archaeology) 257. 232-246 (in Russian). 
Belavin, A. M., Krylasova, N. B. 2008. Drevniaia Afkula: arkheologicheskii kompleks u s. Rozhdestvensk (Ancient Afkula: the Archaeological Complex near the Rozhdestvensk Village). Perm: Perm State Pedagogical University (in Russian).

Belavin, A. M., Krylasova, N. B. 2017 In Povolzhskaya arkheologiya (Volga River Region Archaeology) 19 (1), 284-297 (in Russian).

Golovchansky, G. P., Mel'nichiuk, A. F., Skornyakova, S. V. 2013. In Vaskul, I. O. (ed.). Etnokul'turnye kontakty v epokhu kamnia, bronzy, rannego zheleznogo veka i srednevekov'ia v Severnom Priural'e (EthnicCultural Relations of the Population of the European North-East in Antiquity and the Middle Ages). Series: Materialy po arkheologii Evropeiskogo Severo-Vostoka (Materials on the Archaeology of the European NorthEast) 18. Syktyvkar: Institute of Language, Literature and History, Komi Research Center, Ural Branch of the Russian Academy of Sciences, 133-143 (in Russian).

Golovchanskii, G. P., Mel'nichuk, A. F. 2018. In Vestnik Permskogo universiteta. Seriia «Istoriia» (Bulletin of the Perm University. History Series) 40 (1), 101-111 (in Russian).

Zelentsova, O. V., Kuzina, I. N., Milovanov, S. I., Chernenko, V. V. 2011. In Kostyashov, Z. V. (ed). Baltijskii iantar': Nauka. Kul'tura. Ekonomika: materialy mezhdunarodnogo nauchnogo simpoziuma «Dobycha i obrabotka iantaria na Sambii») (Baltic Amber: Science. Culture. Economics: Proceedings of the International Scientific Symposium "Amber Mining and Processing in Sambia”). Kalilningrad: Kaliningrad Regional Amber Museum, 75-81 (in Russian).

Zelentsova, O. V., Kuzina, I. N., Milovanov, S. I. 2009. In Priroda (Nature) 1128 (8), 45-47 (in Russian).

Krylasova, N. B., Podosenova, Yu. A. 2019. In Vestnik Muzeia arkheologii i etnografii Permskogo Predural'ia (Bulletin of the Museum of Archaeology and Ethnography of the Perm Cis-Urals) IX, 86-93 (in Russian).

Martirosyan, O. V., Bogdasarov, M. A. 2014. In Vestnik Instituta geologii Komi NTS Uro RAN (Vestnik of Institute of Geology of Komi Science Center of Ural Branch RAS). 4. 10-15 (in Russian).

Moryakhina, K. V. 2015. In Krylasova, N. B. (ed.). Trudy Kamskoi arkheologo-etnograficheskoi ekspeditsii (Proceedings of the Kama Archaeological and Ethnographical Expedition) X. Perm: Perm State Humanitarian Pedagogical University, 163-167 (in Russian).

Otchet N.A. Prokosheva ob arkheologicheskikh rabotakh na stroitel'stve Kamskoj GJeS v $1935 \mathrm{~g}$. na Kame i Chusovoi po Otkrytomu listu № 42 (Report by N.A. Prokoshev on Archaeological Work during the Construction of the Kama HPP in 1935 on the Kama and Chusovaya Rivers as per the Open Sheet No. 42). Archive of the Institute for the History of Material Culture, Russian Academy of Sciences. Found 2, dossier 29 (in Russian).

Podosenova, Yu. A. 2017. In Vestnik Muzeia arkheologii i etnografii Permskogo Predural'ia (Bulletin of the Museum of Archaeology and Ethnography of the Perm Cis-Urals) VII, 38-44 (in Russian).

Podoseonova, Yu. A. 2018. In Belavin, A. M. (ed.). Trudy Kamskoi arkheologo-etnograficheskoi ekspeditsii (Proceedings of the Kama Archaeological and Ethnographical Expedition) 14. Perm: Perm State Humanitarian Pedagogical University, 199-204 (in Russian).

Podoseonova, Yu. A. 2018b. In Bagashev, A. N. (ed.). Chelovek i sever: antropologiia, arkheologiia $i$ ekologiia (Man and North: Anthropology, Archaeology, Ecology: Materials of All-Russian Scientific Conference). Tyumen: Tyumen Scientific Center SB RAS, 187-191 (in Russian).

11932. Razvedochnye raboty A.V. Shmidta na Permskoi plotine Sredne-Volgostroia (perepiska i otchety) (Exploration Activities by A.V. Schmidt on the Perm Dam of Srednevolgostroi (Correspondence and Reports)). Archive of the Institute for the History of Material Culture, Russian Academy of Sciences. Found 2, Ar. 127, dossier 8 (in Russian).

Rozenfeldt, R. L. 1978. In Kropotkin, V. V., Matyushin, G. N., et al. (eds.). Problemy sovetskoi arkheologii (Issues of Soviet Archaeology). Moscow: "Nauka" Publ., 197-208 (in Russian).

Rybina, E. A. 2001. Torgovlia srednevekovogo Novgoroda (Trade of Medieval Novgorod). Novgorod: Novgorod State University (in Russian).

Savkevich, S. S. 1970. Iantar' (Amber). Leningrad: "Nedra” Publ. (in Russian).

Sarapulov, A. N., Podoseonova, Yu. A., Kameshchikov, O. Yu., Mokrushin, I. G. 2020. In Belavin, A. M. (ed.). Trudy Kamskoi arkheologo-etnograficheskoi ekspeditsii (Proceedings of the Kama Archaeological and Ethnographical Expedition) XVI. Perm: Perm State Humanitarian Pedagogical University, 21-27. (in Russian).

Spitsyn, A. A. 1892. Drevnosti Kamskoi Cnudi po kollektsii Teploukhovykh (Antiquities of Kama Chud based on the Teploukhovs' Collection). Materialy po arkheologii Rossii (Proceedings for the Archaeology of Russia) 26. Saint Petersburg (in Russian). 
Srebrodol'sky, B. I. 1984. Iantar' (Amber). Moscow: "Nauka" Publ. (in Russian).

Srebrodol'sky, B. I. 1988. Mir iantaria (Мир янтаря). Kiev: "Naukova dumka” Publ. (in Russian).

Talitsky, M. V. Otchet po obsledovaniiu arheologicheskih pamiatnikov basseina r. In'vy (pravyi pritok Kamy) Kudymkarskogo okruga Permskoi oblasti (Report Investigation of archaeological sites in the In'va River basin (Right Tributary of the Kama) in Kudymkar Districr of Perm Oblast). Archive of the Institute for the History of Material Culture, Russian Academy of Sciences. Found 35, dossier 71 (in Russian).

Talitsky, M. V. 1951. In Chernetsov, V. N. (ed.). Materialy i issledovaniia po arkheologii (Materials and Research in Archaeology) 22. Moscow: Academy of Sciences of the USSR, 4-58 (in Russian).

Shapovalov, R. G. 1998. In Gaidukov, P.G., Kazarmshchikova, T. N. (eds.). Novgorod i Novgorodskaia zemlia. Istoriia i arkheologiia (Novgorod and Novgorod Land. History and Archaeology) 12. Veliky Novgorod, 109-120 (in Russian).

Frakei, E. 1990. Iantar' (Amber). Moscow: "Mir" Publ. (in Russian).

Khuzin, F. Sh., Valiullina, S. I. 1986. In Khalikov, A. Kh. (ed.). Volzhskaia Bulgariia i Rus'(k 1000-letiiu russko-bulgarskogo dogovora) (Volga Bulgaria and Rus': to the 1000 th Anniversary of the Russian-Bulgarian Treaty). Kazan: Institute for Language, Literature, and History, Kazan Branch of the USSR Academy of Sciences, 97-116 (in Russian).

Shmyrina, M. E. 2020. In Belavin, A. M. (ed.). Trudy Kamskoi arkheologo-etnograficheskoi ekspeditsii (Proceedings of the Kama Archaeological and Ethnographical Expedition) XVII. Perm: Perm State Humanitarian Pedagogical University, 122-130 (in Russian).

Poulin, J. and Helwig, K. 2014. 'Inside Amber: The Structural Role of Succinic Acid in Class Ia and Class Id Resinite' (in English).

\section{About the Authors:}

Sarapulov Alexey N. Candidate of Historical Sciences, Associate Professor, Perm State Humanitarian Pedagogical University. Sibirskaya Str., 24, Perm, 614990, Russian Federation; ans05@mail.ru

Mokrushin Ivan G. Candidate of Chemical Sciences, Associate Professor, Perm State University. Bukirev Str., 15, Perm, 614990, Russian Federation; mig@psu.ru

Krasnovskikh Marina P. Head of the Laboratory, Perm State University. Bukirev Str., 15, Perm, 614990, Russian Federation; krasnovskih@yandex.ru

Ivanov Petr A. Perm State University. Bukirev Str., 15, 614990, Russian Federation; zukk33@gmail.com

Kamenshchikov Oleg Yu. Head of the Laboratory, Perm State University. Bukirev Str., 15, Perm, 614990, Russian Federation; koy@chemanalysis.ru

Podosenova Yulia A. Candidate of Historical Sciences, Senior Researcher, Associate Professor, Perm Federal Research Center of the Ural Branch of the Russian Academy of Sciences. Lenina Str., 13A, Perm, 614990, Russian Federation; Perm State Humanitarian Pedagogical University. Sibirskaya Str., 24, Perm, 614990, Russian Federation; podosenka@yandex.ru

Статья поступила в журнал 01.04.2021 г. Статья принята к публикации 01.04.2021 г. Авторы внесли равноценный вклад в работу. 